\title{
Epidemiological overview of snakebites in the Baja California peninsula, Mexico (2003-2018)
}

\author{
Jesús M. Rodríguez-Canseco ${ }^{1}$, Gustavo Arnaud-Franco², Everardo Gutiérrez-López and \\ Guillermo Romero-Figueroa ${ }^{1 *}$ \\ ${ }^{1}$ Faculty of Sciences, Universidad Autónoma de Baja California, Ensenada, Baja California; ${ }^{2}$ Environmental Planning Program, Centro de \\ Investigaciones Biológicas del Noroeste, La Paz, Baja California Sur. Mexico
}

\begin{abstract}
Introduction: Ophidian accident is a global public health problem. In Mexico, there is a high incidence of snakebites, which cause medical complications that can leave severe sequelae. Objective: To analyze the epidemiological overview of snake venom poisoning in the Baja California (BC) peninsula within the 2003-2018 period. Method: A descriptive, retrospective analysis of reported cases was carried out, based on data collection and interpretation. Results: $A$ total of 541 records were obtained, out of which 273 occurred in BC and 268 in Baja California Sur (BCS), with an annual average of 17.06 and 16.75, respectively. The incidence rate for $B C$ was 7.62 , while for $B C S$ it was 33.09. The highest annual incidence rate in the state of $B C$ corresponded to southern Ensenada, with a value of 42.3, while in BCS it corresponded to the municipality of Comondú, with a value of 54.04. Conclusions: Epidemiological analyses allow a better local, state and regional understanding of the problem, in order to develop efficient action protocols to face an ophidian accident, as well as to determine the training requirements of medical personnel and establish a support network for the treatment of cases.
\end{abstract}

KEY WORDS: Ophidian accident. Poisonous snakes. Incidence rate. Crotalus.

\section{Panorama epidemiológico de las mordeduras por serpientes en la península de Baja California, México (2003-2018)}

\section{Resumen}

Introducción: El accidente ofídico es un problema de salud pública mundial. En México existe una alta incidencia de mordeduras por serpientes, que provocan complicaciones médicas que pueden dejar secuelas severas. Objetivo: Analizar el panorama epidemiológico del ofidismo en la península de Baja California (BC) en los años 2003-2018. Método: Se hizo un análisis de tipo descriptivo y retrospectivo de los casos presentados, a partir de la recopilación e interpretación de la información. Resultados: Se obtuvieron 541 registros, de los cuales 273 se presentaron en BC y 268 en Baja California Sur (BCS), con un promedio anual de 17.06 y 16.75 respectivamente. La tasa de incidencia para BC fue de 7.62 y para BCS de 33.09. La tasa de incidencia anual más alta en el Estado de BC correspondió al sur de Ensenada, con un valor de 42.3, mientras que en BCS fue en Comondú, con un valor de 54.04. Conclusiones: Los análisis epidemiológicos permiten tener un mejor entendimiento local, estatal y regional de la problemática, para poder desarrollar protocolos de acción eficientes para enfrentar un accidente ofídico, así como para determinar las necesidades de capacitación del personal médico y establecer una red de ayuda para el tratamiento de casos.

PALABRAS CLAVE: Accidente ofídico. Serpientes venenosas. Tasa de incidencia. Crotalus.

\footnotetext{
Correspondence:

*Guillermo Romero-Figueroa

E-mail: gromero4@uabc.edu.mx

0016-3813/O 2021 Academia Nacional de Medicina de México, A.C.. Published by Permanyer. This is an open access article under the CC BY-NC-ND

Date of reception: 07-02-2021

Date of acceptance: 07-10-2021

DOI: $10.24875 / G M M . M 21000617$

Gac Med Mex. 2021;157:559-565

Contents available at PubMed

www.gacetamedicademexico.com license (http://creativecommons.org/licenses/by-nc-nd/4.0/).
} 


\section{Introduction}

Ophidian accidents correspond to injuries caused by the bite of a snake (venomous or non-venomous) that result in any type of harm. In the case of venomous snakes, the bite includes inoculation of a toxic substance or venom, which causes tissue damage and local or systemic pathophysiological alterations of varying severity ${ }^{1}$. The World Health Organization considers this type of accident a public health problem that causes between 1.8 and 2.7 million cases of envenoming annually in the world, which result in between 80 and 140 thousand deaths every year ${ }^{2}$. Most affected regions are Asia, Africa and Latin America, where the largest diversity of these reptiles is found, with rural populations being the most vulnerable group ${ }^{3}$. In Mexico, the occurrence of ophidian accidents (or ophidism) has varied over time. In the 199495 period, 627 cases were recorded, with 30 deaths, whereas in 1997, a considerable increase in the number of cases was reported, with 27,480 registries and 136 deaths $^{4}$, while average annual registration in the years comprised between 2003 and 2018 was 3,7005.

Mexico is ranked first in the American continent in terms of venomous herpetofauna, represented by two families of snakes with venom that is potentially deadly for humans: a) Viperidae (represented by 10 genera and 64 species), which includes rattlesnakes, Bothros asper (terciopelo or nauyaca) and Agkistrodon bilineatus (cantil), and b) Elapidae (represented by three genera and 10 species), which includes coralillos or coral snakes ${ }^{6}$. The States with the highest incidence of snakebites are Veracruz, Oaxaca, San Luis Potosí, Hidalgo and Puebla ${ }^{7}$, which is attributable to their geographic and climatic characteristics, which favor a wide diversity of ophidians ${ }^{8}$. In contrast, in the Baja California (BC) peninsula, where 20 genera and 28 species of snakes are distributed ${ }^{9}$, there are only seven venomous species, which correspond to rattlesnakes $^{10}$. In this region, snakebite registry is lower than in other Mexican States ${ }^{4}$.

The $\mathrm{BC}$ peninsula is a territory with a wide-ranging surface $\left(200,000 \mathrm{~km}^{2}\right)$, made up of three main regions according to their climate and biological composition: 1) Mediterranean-temperate region, located in the northwest, with a temperate sub-humid climate and presence of rainfall in winter; 2) tropical region, located at extreme south in the area known as the Cape region, with winter and summer rainfall, and 3 ) desert region, located between the former two, with a very dry-semi-warm climate, with winter and summer rainfall, covering $60 \%$ of the peninsular surface ${ }^{11-13}$. These three regions are subdivided into 14 ecoregions, defined by the composition of their species and their ecological dynamics ${ }^{14}$.

Although snakebite registry is lower in the peninsula in comparison with other regions of Mexico ${ }^{4}$, the medical complications resulting from these accidents can be severe, not only due to the possibility of death, but also because of the sequels envenoming can originate $^{15}$, as well as those resulting from the application of inadequate medical care ${ }^{16}$. Regarding both peninsular States, BC has a population of 3,583,605 inhabitants (46 people per $\mathrm{km}^{2}$ ), out of which $92.2 \%$ are concentrated in urban areas and $7.7 \%$ in rural areas, while in Baja California Sur (BCS), the population is 809,833 inhabitants (10 people per $\mathrm{km}^{2}$ ), with $86.1 \%$ concentrating in urban areas and $13.8 \%$ in rural areas $^{17-19}$. Here, the lack of anti-venom or fabotherapic agents availability, as well as the large distances between urban centers where hospital care can be obtained, exacerbate the problem, since the hospitals that can provide the best medical care are at extreme north (Tijuana, Ensenada and Mexicali) and at extreme south (La Paz and Los Cabos), separated by a distance of more than $1,000 \mathrm{~km}$.

In this context, the purpose of this study was to analyze the epidemiological outlook of ophidian accidents in the BC peninsula for the 2003-2018 period.

\section{Materials and methods}

Data on snakebite incidence in the states of $B C$ and BCS were obtained from the Epidemiological Bulletin, published by the National Epidemiological Surveillance System, and the Unique Information System of the Ministry of Health of the Federal Government of Mexico. Given that the information provided by said bulletin does not include the geo-localization of the place where the incident occurred by municipality or jurisdiction, the data were supplemented with information from the State Epidemiology Department of the BC Institute of Public Health Services and the BCS Department of Public Health Services in order to group them by State, municipality and jurisdiction. BC is made up of five municipalities, divided into four jurisdictions, while BCS is also made up of five municipalities, each one representing one jurisdiction.

Snakebite registries annual averages were estimated, as well as the incidence rate (total number of cases divided by total population and multiplied by 100,000 
Table 1. Total ophidian accidents and annual rate in Baja California (BC), Baja California Sur (BCS) and Mexico (Mx)

\begin{tabular}{|c|c|c|c|c|c|c|}
\hline Year & Total BC & Rate BC & Total BCS & Rate BCS & Total Mx & Rate Mx \\
\hline 2003 & 17 & 0.47 & 26 & 3.21 & 2,666 & 2.22 \\
\hline 2004 & 9 & 0.25 & 26 & 3.21 & 3,229 & 2.69 \\
\hline 2005 & 19 & 0.53 & 16 & 1.98 & 3,515 & 2.93 \\
\hline 2006 & 10 & 0.28 & 21 & 2.59 & 3,701 & 3.09 \\
\hline 2007 & 7 & 0.2 & 19 & 2.35 & 3,351 & 2.79 \\
\hline 2008 & 26 & 0.73 & 15 & 1.85 & 3,797 & 3.17 \\
\hline 2009 & 11 & 0.31 & 14 & 1.73 & 3,725 & 3.11 \\
\hline 2010 & 15 & 0.42 & 18 & 2.22 & 3,449 & 2.88 \\
\hline 2011 & 24 & 0.67 & 7 & 0.86 & 3,535 & 2.95 \\
\hline 2012 & 24 & 0.67 & 7 & 0.86 & 4,225 & 3.52 \\
\hline 2013 & 25 & 0.7 & 15 & 1.85 & 3,961 & 3.3 \\
\hline 2014 & 12 & 0.33 & 14 & 1.73 & 4,430 & 3.69 \\
\hline 2015 & 21 & 0.59 & 11 & 1.36 & 4,378 & 3.65 \\
\hline 2016 & 12 & 0.33 & 18 & 2.22 & 3,790 & 3.16 \\
\hline 2017 & 15 & 0.42 & 16 & 1.98 & 3,700 & 3.08 \\
\hline 2018 & 26 & 0.73 & 25 & 3.09 & 3,726 & 3.11 \\
\hline Total & 273 & 7.62 & 268 & 33.09 & 59,178 & 49.34 \\
\hline Average & 17.06 & 0.48 & 16.75 & 2.07 & $3,698.63$ & 3.08 \\
\hline Population & $3,584,605$ & & 809,833 & & $119,938,473$ & \\
\hline
\end{tabular}

population), in order for bias in the differences between the number of inhabitants of the peninsula, State and jurisdiction to be avoided. Total number of registries was compared with those of the entire country for the 20032018 period. Incidence rates annual distribution, as well as weekly averages, were expressed in a line chart.

Ophidian accidents geographical distribution was incorporated into a map using $\operatorname{ArcGIS}^{\circledR} 10.2\left(\right.$ ESRI $\left.^{\odot}\right)$ and the SIGepi program, v. 1.4, for estimating the smoothed incidence rates, with local smoothing being applied with the moving average technique with a vicinity distance of $10 \mathrm{~km}$ (smoothing has the purpose to reduce the variability generated by unequal population size between municipalities). For stabilization, municipal rates calculation was carried out with cumulative information of the studied years ${ }^{20,21}$.

\section{Results}

A total of 541 ophidian accident registries were obtained for the 2003-2018 period at the BC peninsula, out of which 273 occurred in BC and 268 in BCS, with an annual average of 17.06 and 16.75 , respectively, which accounted for 0.46 and $0.45 \%$ of total cases in Mexico, with an incidence rate for $\mathrm{BC}$ of 7.62 and 33.09 for BCS (Table 1). The years with the highest number of registries in BC were 2008 and 2018 with 26 cases, while for BCS it was the years 2003, 2004 and 2018 , with 26 and 25 registries. The years with the lowest number of cases were 2004 and 2007 for BC, and 2011 and 2012 for BCS (Table 1).

Although ophidian accidents annual rate was higher in BCS in comparison with BC, it was also higher with regard to the national rate for 2003 and 2004, and equal in 2018 (Fig. 1).

As for distribution of the cases in time in both States, they were constant during all months of the year, with an increase by the end of spring (June) and a decrease in autumn (October) (Fig. 2). On these registries, men were most commonly affected, with a total of 374 cases $(69 \%)$, while 167 cases $(31 \%)$ involved women. 
Ophidian accident cases 2003-2018 (annual rate)

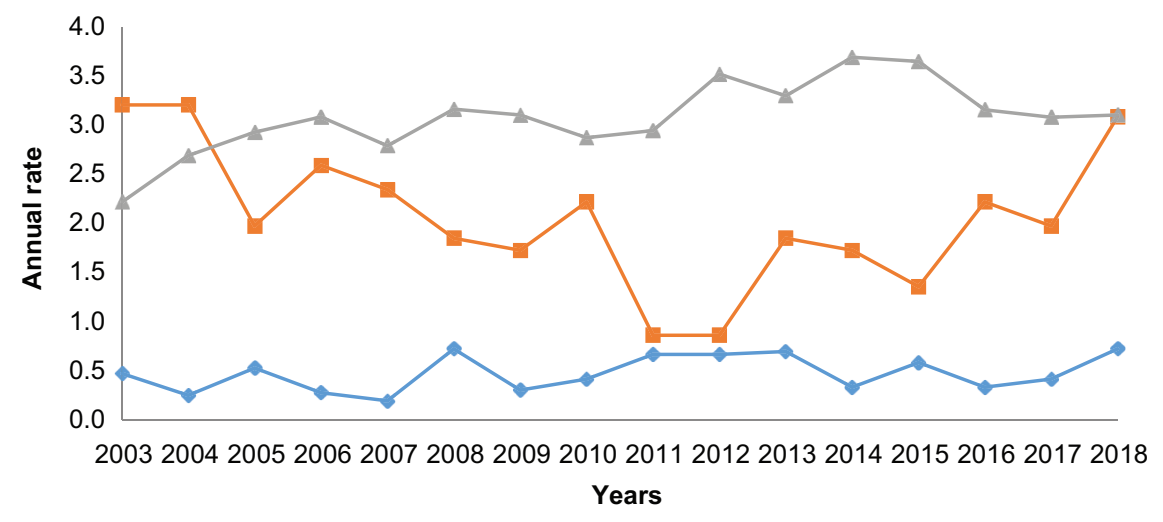

$\multimap$ BAJA CALIFORNIA $\multimap$ BAJA CALIFORNIA SUR $\longleftarrow$ MEXICO

Figura 1. Ophidian accidents annual rate in Baja California, Baja California Sur and Mexico.

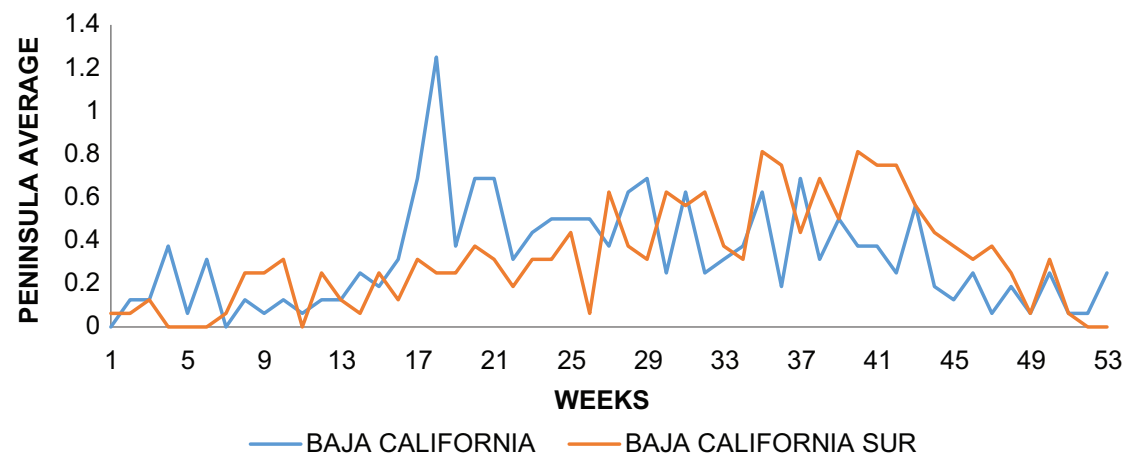

Figure 2. Ophidian accidents weekly average in Baja California and Baja California Sur.

Regarding cumulative annual incidence rate by $B C$ jurisdiction, the highest was recorded in jurisdiction IV, which corresponded to the south of the Ensenada municipality, with a value of 42.3 , while the lowest rate occurred in jurisdiction II, corresponding to the municipalities of Tijuana, Tecate and Playas del Rosarito, with a value of 3.71 (Table 2) (Fig. 3). As for BCS, registries by municipality comprised only the 20032005 and 2012-2016 periods, with a total of 132 cases. The highest rate was documented in the Comondú municipality, with a value of 54.04 , while the lowest rate occurred in the municipality of Loreto, where there were no cases (Table 3) (Fig. 3).

\section{Discussion}

Ophidism is a public health problem in Mexico due to the number of annual cases ${ }^{4,5,16}$. Its impact on the health of those who are affected by it depends on several factors, such as the amount and characteristics of inoculated venom, which can vary according to the species involved ${ }^{22}$, as well as to the promptness of care and access to appropriate treatment ${ }^{23}$, which in the $\mathrm{BC}$ peninsula depends on the locality the ophidian accident occurs at, since distances to hospital centers can be considerably long, which implies a significant number of hours before being able to receive medical attention.

Interaction between snakes and humans in this region of Mexico occurs mainly in rural areas. In the BC peninsula, epidemiological information on ophidian envenoming is limited, since not all those affected attend medical facilities, due to the remoteness of localities, which is why they are not registered by the health system. 
Table 2. Ophidian accident cases and annual incidence rate in Baja California by jurisdiction

\begin{tabular}{|c|c|c|c|c|c|c|c|c|c|c|}
\hline Year & Mexicali & Rate & $\begin{array}{c}\text { Tijuana, Tecate and Playas } \\
\text { de Rosarito }\end{array}$ & Rate & $\begin{array}{l}\text { North of } \\
\text { Ensenada }\end{array}$ & Rate & $\begin{array}{l}\text { South of } \\
\text { Ensenada }\end{array}$ & Rate & Total & Rate \\
\hline 2003 & 2 & 0.19 & 5 & 0.25 & 5 & 1.17 & 2 & 1.84 & 14 & 0.4 \\
\hline 2004 & 3 & 0.28 & 0 & 0 & 4 & 0.94 & 3 & 2.76 & 10 & 0.3 \\
\hline 2005 & 5 & 0.47 & 2 & 0.1 & 12 & 2.81 & 4 & 3.68 & 23 & 0.6 \\
\hline 2006 & 3 & 0.28 & 0 & 0 & 7 & 1.64 & 1 & 0.92 & 11 & 0.3 \\
\hline 2007 & 2 & 0.19 & 2 & 0.1 & 2 & 0.47 & 2 & 1.84 & 8 & 0.2 \\
\hline 2008 & 12 & 1.14 & 9 & 0.45 & 3 & 0.7 & 0 & 0 & 24 & 0.7 \\
\hline 2009 & 8 & 0.76 & 2 & 0.1 & 1 & 0.23 & 1 & 0.92 & 12 & 0.3 \\
\hline 2010 & 7 & 0.66 & 3 & 0.15 & 5 & 1.17 & 2 & 1.84 & 17 & 0.5 \\
\hline 2011 & 4 & 0.38 & 14 & 0.7 & 4 & 0.94 & 4 & 3.68 & 26 & 0.7 \\
\hline 2012 & 8 & 0.76 & 3 & 0.15 & 5 & 1.17 & 8 & 7.36 & 24 & 0.7 \\
\hline 2013 & 7 & 0.66 & 4 & 0.2 & 10 & 2.34 & 4 & 3.68 & 25 & 0.7 \\
\hline 2014 & 4 & 0.38 & 6 & 0.3 & 2 & 0.47 & 1 & 0.92 & 13 & 0.4 \\
\hline 2015 & 7 & 0.66 & 5 & 0.25 & 6 & 1.41 & 6 & 5.52 & 24 & 0.7 \\
\hline 2016 & 4 & 0.38 & 7 & 0.35 & 1 & 0.23 & 1 & 0.92 & 13 & 0.4 \\
\hline 2017 & 6 & 0.57 & 7 & 0.35 & 2 & 0.47 & 0 & 0 & 15 & 0.4 \\
\hline 2018 & 8 & 0.76 & 5 & 0.25 & 6 & 1.41 & 7 & 6.44 & 26 & 0.7 \\
\hline Total & 90 & 8.55 & 74 & 3.71 & 75 & 17.6 & 46 & 42.3 & 285 & 8 \\
\hline
\end{tabular}

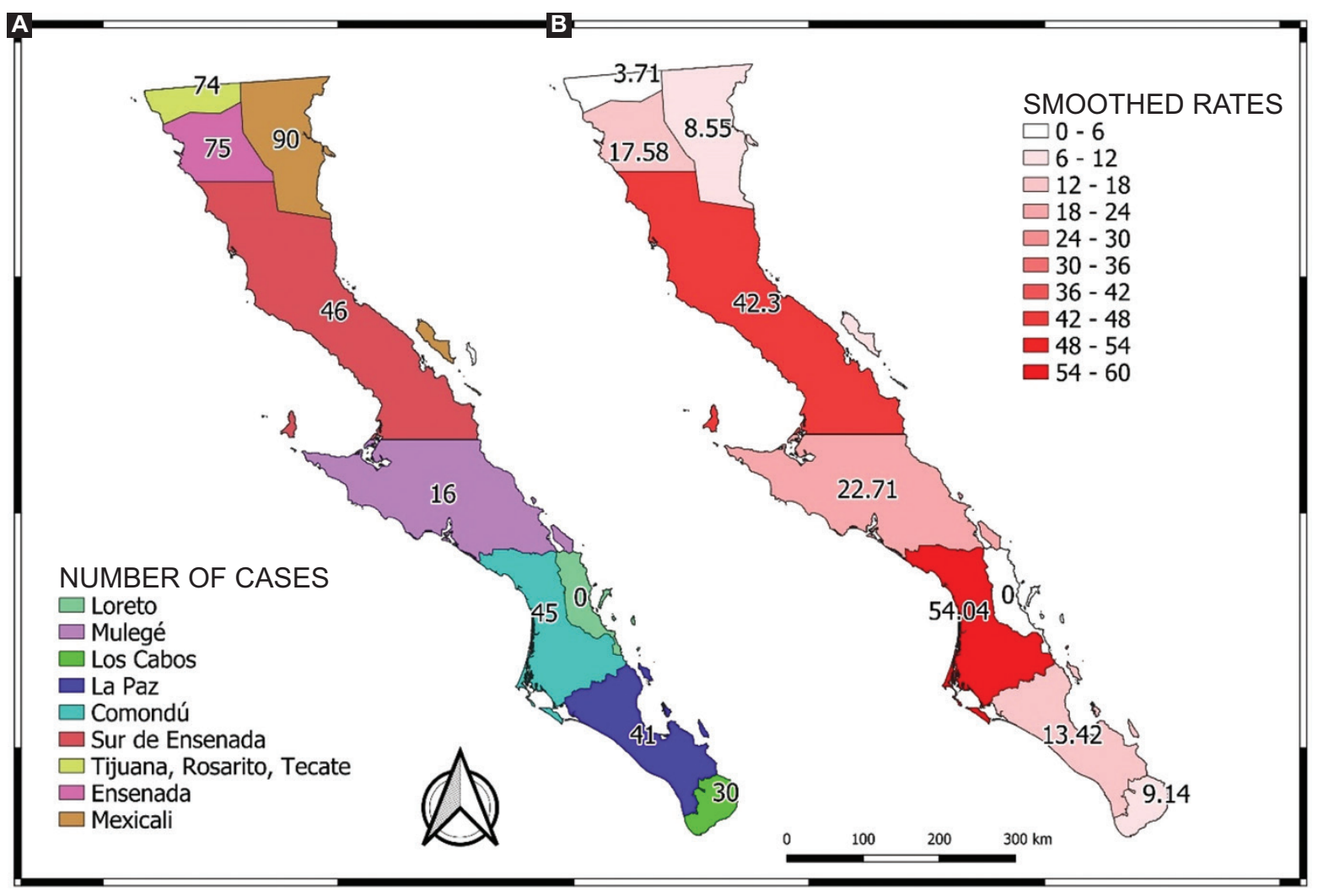

Figure 3. Snakebite cases number geographic variation (A) and incidence rate (accidents/100,000 population) (B), during the $2003-2018$ period in the Baja California peninsula. 
Table 3. Ophidian accident cases and annual incidence rates by municipality in Baja California Sur

\begin{tabular}{|l|l|l|l|l|l|l|l|l|l|l|l|l|}
\hline Year & Comondú & Rate & Mulegé & Rate & La Paz & Rate & Los Cabos & Rate & Loreto & Rate & Total & Rate \\
\hline 2003 & 11 & 13.2 & 2 & 2.84 & 10 & 3.27 & 4 & 1.22 & 0 & 0 & 27 & 3.33 \\
\hline 2004 & 11 & 13.2 & 1 & 1.42 & 11 & 3.6 & 3 & 0.91 & 0 & 0 & 26 & 3.21 \\
\hline 2005 & 2 & 2.4 & 0 & 0 & 1 & 0.33 & 2 & 0.61 & 0 & 0 & 5 & 0.62 \\
\hline 2012 & 4 & 4.8 & 5 & 7.1 & 3 & 0.98 & 2 & 0.61 & 0 & 0 & 14 & 1.73 \\
\hline 2013 & 4 & 4.8 & 3 & 4.26 & 2 & 0.65 & 7 & 2.13 & 0 & 0 & 16 & 1.98 \\
\hline 2014 & 6 & 7.21 & 0 & 0 & 7 & 2.29 & 3 & 0.91 & 0 & 0 & 16 & 1.98 \\
\hline 2015 & 3 & 3.6 & 1 & 1.42 & 2 & 0.65 & 4 & 1.22 & 0 & 0 & 10 & 1.23 \\
\hline 2016 & 4 & 4.8 & 4 & 5.68 & 5 & 1.64 & 5 & 1.52 & 0 & 0 & 18 & 2.22 \\
\hline Total & 45 & 54 & 16 & 22.7 & 41 & 13.4 & 30 & 9.1 & 0 & 0 & 132 & 16.3 \\
\hline
\end{tabular}

Monthly occurrence of cases in the $\mathrm{BC}$ peninsula is similar to that in other regions of the country, with a preponderance during the warmest and rainiest month ${ }^{24-26}$; however, in the peninsula, the occurrence of snakebites is throughout the entire year. Men are more commonly affected than women, which is similar to other regions of Mexico ${ }^{1,24-26}$ and other countries ${ }^{27-30}$.

For the national registry of cases, the Epidemiological Weekly Bulletin, published by the Ministry of Health through the National Epidemiological Surveillance System, is highly useful, because it allows knowing the number of snakebite cases by State; however, there is information that is not considered, but that is collected by the States' Health Services, which classify it at the level of jurisdiction or municipality. Even so, there are important gaps in the collected information, such as the species involved, which could allow the most commonly involved species to be identified. Pictures of the involved snake can be identified by regional specialists. In addition to the person's gender, it is also necessary to record his/ her age, anatomical location of the bite, activity the involved person was performing at the time of the bite, time between the bite and anti-venom or fabotherapic agent application, number of anti-venom applied doses and length of stay at the medical unit.

In this context, epidemiological analyses allow having a better understanding of the problem at the local, state and regional levels, in order to be able to develop efficient action protocols for dealing with an ophidian accident, as well as to determine medical personnel training needs and to establish a support network for the treatment of cases, which is particularly important in the BC peninsula due to its length of more than one thousand kilometers. Although the main treatment for taking care of an ophidian accident is anti-venom or fabotherapic agents administration, since after the bite the first two hours are crucial for mitigating the venom effects, ${ }^{23}$ there are still doctors who are reluctant about their use.

Although ophidism is relatively low in the $\mathrm{BC}$ peninsula, in BCS, the State with the lowest population density in the country, its rate is close to the national mean, and even exceeds it in one year. In BC, despite having almost the same number of cases than BCS, its rate is lower because its population is 3:1 in relation to BCS.

\section{Conclusions}

The frequency of ophidian accidents in the $\mathrm{BC}$ peninsula is lower than in other States of Mexico; however, in BCS, the incidence rate is high because it is the State with the lowest demographic density.

There are information gaps on each snakebite case cared for at medical services, including the species of the involved snake.

Epidemiological information related to ophidian accidents is essential for the municipal and regional magnitude of the problem to be evaluated in order for guidelines for the management of resources and the training of medical personnel for the treatment of snakebites to be developed.

\section{Acknowledgments}

The authors thank CONACYT for the support provided through the student scholarship for the 
development of this project. The authors also thank Universidad Autónoma de Baja California and the State Health Ministries for the help provided.

\section{Funding}

This research was funded by CONACYT through student grant no. 483968 .

\section{Conflict of interests}

The authors declare that there are no conflicts of interest related to the statements expressed in this article.

\section{Ethical disclosures}

Protection of human and animal subjects. The authors declare that no experiments were performed on humans or animals for this research.

Confidentiality of data. The authors declare that no patient data appear in this article.

Right to privacy and informed consent. The authors declare that no patient data appear in this article.

\section{References}

1. Secretaría de Salud. Diagnóstico y tratamiento de las mordeduras de serpientes venenosas. Guía de Práctica Clínica. México: Secretaría de Salud, Consejo de Salubridad General; 2010.

2. Organización Mundial de la Salud. Mordedura de serpientes venenosas [Internet]. Organización Mundial de la Salud; 2018 Available at: https:// www.who.int/es/news-room/fact-sheets/detail/snakebite-envenoming

3. Chippaux JP. Estimating the global burden of snakebite can help to improve management. PloS Med. 2008;5(11):e221.

4. González-Rivera A, Chico-Aldama P, Domínguez-Viveros W, Iracheta-Gerez ML, López-Alquicira M, Cuellar-Ramírez A, et al. Epidemiología de las mordeduras por serpiente. Su simbolismo. Acta Pediatr Mex. 2009;30(3):182-91.

5. Secretaría de Salud. Boletín epidemiológico. Sistema Nacional de Vigilancia Epidemiológica. Sistema Único de Información. México: Dirección General de Epidemiología. 2018;52(35):1-62.

6. Neri-Castro E, Bérnard-Valle M, Alagón-Cano A. Reptiles venenosos de México. Revista Digital Universitaria [Internet]. 2014;15(11). Available at: http://www.revista.unam.mx/vol.15/num11/art86/art86.pdf

7. Siria-Hernández CG, Arellano-Bravo A. Mordeduras por serpiente venenosa: panorama epidemiológico en México. Salud Publica Mex. 2009;51(2):95-6

8. Flores-Villela O, Goyenechea I. Patrones de distribución de anfibios y reptiles en México. In: Morrone JJ, Llorente Bousquets J, publishers. Una perspectiva latinoamericana de la biogeografía. Mexico: CONABIO, Facultad de Ciencias, Universidad Nacional Autónoma de México; 2003. pp. 289-296
9. Grismer LL. The amphibians and reptiles of Baja California, its Pacific islands, and the islands in the Sea of Cortes: natural history, distribution and identification. Berkeley: University of California Press; 2002.

10. Uetz P, Freed P, Hošek J, editores. The Reptile Database [Internet]. The Reptile Database [last update: May 22, 2020; accessed: July 2020]. Available at: http://www.reptile-database.org

11. García E. Climas. Catálogo de metadatos geográficos. Comisión Nacional para el Conocimiento y Uso de la Biodiversidad; 1998.

12. Corral JAR, Medina García G, Meza Sánchez R, Padilla G, Serrano Altamirano V. Estadísticas climatológicas básicas del estado de Baja California (periodo 1961-2003). Libro Técnico Núm. 1. Ciudad Obregón, Sonora, México: INIFAP-CIRNO; 2006.

13. Salinas-Zavala CA, Leyva-Contreras A, LluchBelda D, Díaz-Rivera E. Distribución geográfica y variabilidad climática de los regímenes pluviométricos en Baja California Sur, México. Atmósfera. 1990:3:217-37.

14. González-Abraham CE, Garcillán PP, Ezcurra E. Ecorregiones de la Península de Baja California: Una síntesis. Bol Soc Bot Mex. 2010;87:69-82.

15. Arnaud G, Carbajal-Saucedo A, Pozas-Ocampo F. Comprendiendo el veneno de las serpientes de cascabel: componentes, efectos y uso potencial. Áreas Naturales Protegidas Scripta. 2019;5(2):39-56.

16. Zúñiga-Carrasco IR, Caro-Lozano J. Aspectos clínicos y epidemiológicos de la mordedura de serpientes en México. Evid Med Invest Salud. 2013;6(4):125-36.

17. Instituto Nacional de Estadística y Geografía. Población rural y urbana. Censos y conteos de población y vivienda. Mexico: Gobierno de México, Instituto Nacional de Estadística y Geografía; 2019.

18. Gobierno de Baja California. Apuntes de población de Baja California. Mexico: COPLADE; 2013

19. Gobierno de Baja California Sur. Demografía. Anuario Estadístico. Mexico: Secretaría de Salud; 2017.

20. Martínez-Piedra R, Loyola-Elizondo E, Vidaurre-Arenas M, Nájera-Aguilar P. Paquetes de programas de mapeo y análisis espacial en epidemiología y salud pública. Bol Epidemiol OPS. 2004;25(4):1-9.

21. Leynaud GC, Reati GJ. Identificación de las zonas de riesgo ofídico en Córdoba, Argentina, mediante el programa SIGEpi. Rev Panam Salud Publica. 2009;26(1):64-9.

22. Arnaud G, Cordero-Tapia A, Ortíz-Avila V, Moctezuma-González CE, Tejocote-Pérez M, Carbajal-Saucedo A. Comparison of biological and biochemical characteristics of venom from rattlesnakes in the southern Baja California Peninsula. Toxicon. 2018;148 (2018):197-201.

23. Gil-Alarcón G, Sánchez-Villegas MC, Reynoso VH. Tratamiento prehospitalario del accidente ofídico: revisión, actualización y problemática actual. Gac Med Mex. 2011;147:195-208.

24. Almaraz-Vidal D. Las serpientes venenosas de importancia médica de la región de Las Grandes Montañas de Veracruz, México: aspectos ecológicos y accidentes ofídicos. Revista Mundo Investigación. 2016;2(1):173-80.

25. Juárez-Villa JD, López-de León J, Rodríguez-Mandujano M, Echegollen-Guzmán A. Mordedura de serpiente en el Hospital General de Ciudad Victoria, Tamaulipas. Evid Med Invest Salud. 2016;9:92-7.

26. Luna-Trejo J. Análisis epidemiológico del accidente por animales venenosos en el Estado de México del 2004 al 2016. Tesis de licenciatura en biología. Toluca, Estado de México: Universidad Autónoma del Estado de México, Facultad de Ciencias; 2018.

27. Matute-Martínez CF Sánchez-Sierra LE Barahona-López DM, Laínez-Mejía JL, Matute-Martínez FJ, Perdomo-Vaquero R. Caracterización de pacientes que sufrieron mordedura de serpiente, atendidos en hospital público de Juticalpa, Olancho. Rev Fac Cienc Med. 2016(enero-junio):18-26.

28. Rojas-Bárcenas AM. Informe de evento. Accidente ofídico [Internet]. Colombia: Instituto Nacional de Salud; 2017. Available at: https://www. ins.gov.co/buscador-eventos/Informesdeevento/ACCIDENTE\%200F\%C3\%8DDICO_2018.pdf

29. Sevilla-Sánchez MJ, Mora-Obando D, Calderón JJ, Guerrero-Vargas JA, Ayerbe-González S. Accidente ofídico en el departamento de Nariño, Colombia: análisis retrospectivo, 20082017. Biomédica. 2019;39:715-36.

30. Vélez-Alarcón LH, Real-Cotto JJ, Idrovo-Castro KJ, Alvarado-Franco HJ, Jaramillo-Feijoo LE, Ordóñez-Sánchez JL. Caracterización del accidente por mordedura de serpiente, atendidos en Unidades de Salud, Zona 5, Ecuador. Revista Científica INSPILIP. 2019;3(1). 